\title{
Driving Mechanism of China's Tourism Foreign Direct Investment in the United States
}

\author{
YANG Yingying ${ }^{1, a}$, CHEN Ying ${ }^{2, b *}$ \\ ${ }^{1}$ School of Geography and Tourism, Shaanxi Normal University, SNNU, Xi'an, P.R. China \\ ${ }^{2}$ School of Geography and Tourism, Shaanxi Normal University, SNNU, Xi'an, P.R. China
}

\begin{abstract}
Based on the 2000-2018 data of China's direct investment in U.S. tourism industry, this paper used the random effect models to quantitatively measure the driving mechanism of Chinese direct investment in U.S. tourism industry. The results showed that: China's direct investment in U.S. tourism is mainly influenced by the four driving forces of economic development, tourism development, cultural affinity, investment environment and system. "Cultural affinity" is the characteristic of the U. S. which is different from the FDI of Chinese tourism in the global perspective.
\end{abstract}

\section{INTRODUCTION}

With the rapid rise of China's outbound tourism, the State Council and the Ministry of Culture and Tourism have issued a series of documents advising Chinese companies to "go globally" to expand the international tourism market. As one of the forms of transnational operations, outward foreign direct investment is an economic activity that exports capital, equipment, technology or management to foreign countries, and is realized in the form of greenfield investment, mergers and acquisitions and joint ventures ${ }^{[1]}$. Unlike franchise and management contracts, the ownership of FDI enterprises belongs to the host country and is not easily restricted by laws and policies of the host country, which can prompt the tourism multinational enterprises to reduce costs and improve profitability; Furthermore, tourism FDI can directly gain effective control of foreign enterprises. Combined with the fact that China's outbound tourism seriously consumes foreign exchange, tourism FDI can not only effectively promote currency withdrawal and reduce foreign exchange leakage ${ }^{[2]}$, but also help Chinese companies establish a national brand in the international tourism market ${ }^{[3]}$. In the development of China's outward foreign direct investment in the tourism industry, the United States has gradually become the main investment host country due to its strong market size. According to the Bulletin of China's Outward Foreign Direct Investment issued by the Ministry of Commerce of China, China 's FDI stock in the US accommodation and catering industry reached $14.75 \%$ of the total in 2017, and the United States was the largest recipient of FDI in China 's accommodation and catering industry; Moreover, most of China's large-scale hotel acquisitions have taken place in the United States (for example, HNA Tourism Group acquired $25 \%$ equity in the famous Carlson Hotel Group and Hilton Hotel in the United States with 8.38 billion USD in 2016-20170). The American case is a pioneer in the study of the microscale of FDI in China's tourism industry.

The literature on "Go globally" strategy of China's tourism industry takes "transnational management" as the main hot spot. From the perspective of economics and marketing, the development strategies, development models, and revenue management of transnational operation of tourism companies ${ }^{[4-5]}$ were proposed. In addition, some of the articles put forward the transnational management idea from the perspectives of micro travel agencies and hotel industry, among which only a small number of literatures were related to tourism FDI, a more focused proposition. The practice of FDI in China's tourism industry began in the late 1980s, but academic research began in the early 21 st century, and the achievements were mainly to explain the influencing factors of tourism FDI from two aspects of the domestic and host countries: (1) China's perspective: China's tourism output value, inbound and outbound tourism scale and tourism expenditure, the trade level and geographic location of each province/city/district ${ }^{[6-7]}$; (2) Host country perspective: the scale of inbound tourism from China, tourism economic scale, opening degree of economy, human capital, social development and political environment are the main factors that affect its acceptance of China's tourism FDI ${ }^{[8-9]}$. In recent years, the promotion of the "Belt and Road" initiative has provided better resource location conditions, policy guarantees, consumer market and financial support for the development of China's tourism FDI. However, China's tourism FDI still faces development problems such as small scale, lack of brand influence, low security, and information asymmetry ${ }^{[10]}$.

In conclusion, the research on FDI in China's tourism industry has not received much attention in the academic

ayyyheart@126.com; bchenying@snnu.edu.cn 
world, and the research perspective is relatively macro. Existing literature has made theoretical contributions to the FDI in China's tourism industry, but there is a problem of homogenizing the research area. In view of the pioneering nature of the United States in the study of China's tourism FDI, this paper selected the United States as the research area, combined with economic methods, based on U.S. national and state-level data, to quantitatively measure China's driving mechanism for US tourism OFDI. The purpose was to make up for the lack of research on Chinese tourism FDI, and to grasp the regional development trend and development ideas of Chinese tourism FDI from the practical perspective, so as to provide a reference for Chinese enterprises to make decisions on their direct investment in the us tourism industry.

\section{RESEARCH METHODS AND DATA SOURCES}

\subsection{Indicator Selection and Data Source}

To summarize the previous research on tourism FDI, this paper selected market size and purchasing power, opening degree of economy, tourism development level, policy and environment as influencing factors; Combined with the relevant research on American FDI, the indicator of cultural proximity was included to jointly constitute China's basic framework for analyzing the driving mechanism of American tourism:

Tourism FDI. As an explained variable for this study, China's FDI in the US tourism industry was composed of two statistics, Real Estate and Hospitality and Transport and Infrastructure. The data comes from Rhodium group and be described as TFDI.

Market size. Larger market size and higher market potential will attract larger-scale FDI ${ }^{[11]}$. The GDP of American states was selected as the representative variable. The data comes from US Bureau of Economic Analysis.

Purchasing power. On the one hand, stronger purchasing power will attract more FDI; on the other hand, according to the actual national conditions of China and the United States, the products of enterprises in developing countries are better suited to the needs of regions with similar consumption levels in the country, so the influence direction of purchasing power on FDI is uncertain ${ }^{[12]}$. The GDP per capita of each state in the United Sates was taken as the representative variable. The data comes from US Bureau of Economic Analysis and be described as PGDP.

The opening degree of economy. In the service industry where production and consumption are inseparable, economic liberalization is the key to attracting FDI. The higher the degree of economic liberalization, the higher the degree of marketization and the less government regulation ${ }^{[13]}$. The degree of trade dependence was used to represent the opening degree of economy in each state, calculated as the ratio of the total imports and exports from China to the United States to the state 's GDP. The data comes from US Bureau of Economic Analysis and be described as Trade.

Tourism development level. The more active the tourism economy is in regions with a higher level of tourism development, the easier it is to attract foreign investment in the tourism industry ${ }^{[14]}$. The proportion of tourism output value of each state to GDP was used to measure the development level of each state's tourism economy. According to statistics, the output value of the tourism industry is composed of the output values of three industries: transportation and warehousing, art/entertainment/leisure, and accommodation services. The data comes from US International Trade Administration and US-China business council and be described as TGDP.

Investment policies and environment. They refer to the soft environment of the host country, such as the legal environment, institutional environment, political stability, and acceptance of foreign investment. The United States belongs to a federal state, and each state has an independent legal and economic system. Therefore, the institutional and environmental differences between states are also factors to be considered. The more sound the investment policies and environment of a state, the more open-minded the investment attitude towards China, and the more investment will be attracted to China ${ }^{[8]}$. The FDI values from China to the states of US were selected as the representative variables. The data comes from Rhodium group and be described as FDI.

Cultural affinity. This concept was proposed by Straubhaar (1991). The greater the similarity between the two countries in terms of language, religious beliefs, customs, etc., the more conducive to promoting trade between the two countries ${ }^{[15]}$. The United States is a typical immigration country. This study predicted that cultural affinity would have an impact on tourism FDI. From the existing research, it can be known that Chinese direct investment in the United States tends to be in areas where Chinese people congregate ${ }^{[22-23]}$. Limited by the availability of state-level data on Chinese immigrants, this article used the number of Asian populations in the US community survey data released by the US Census Bureau as a substitute variable for Chinese immigration data, to reflect the influence of cultural affinity on Chinese tourism FDI. The data comes from US Census Bureau and be described as Asian.

\subsection{Individual effect model}

This article used the individual effect model in the panel data model as a research tool. When applying individual effect models to the panel data analysis, the random effect model and fixed effect model were generated according to whether unobserved effects that did not change with time were correlated with explanatory variables or not. The former was assumed to be independent of explanatory variables, while the latter was assumed dependent. In the actual panel data analysis, whether to choose a random effect model or a fixed effect model can be determined by the excessive constraint conditions detected by Hausman test method. In order to eliminate the differences brought by different 
dimensions, this paper took the logarithms of all data. The panel data model was constructed as follows:

The fixed effect model:

$$
\begin{aligned}
& \text { LnTFDI }_{i t=} \alpha_{i+} \beta_{1} \operatorname{LnGDP}_{i t}+\beta_{2} \operatorname{LnPGDP}_{i t}+\beta_{3} \text { LnTrade }_{i t}+ \\
& \beta_{4} \text { LnTGDP }_{i t}+\beta_{5} \text { LnFDI }_{i t}+\beta_{6} \text { LnAsian }_{i t}+u_{i t}
\end{aligned}
$$

The random effect model:

$$
\begin{aligned}
& \text { LnTFDI }_{i t=} \beta_{0}+\beta_{1} \operatorname{LnGDP}_{i t}+\beta_{2} \operatorname{LnPGDP}_{i t}+\beta_{3} \text { LnTrade }_{i t}+ \\
& \beta_{4} \operatorname{LnTGDP}_{i t}+\beta_{5} \operatorname{LnFDI}_{i t}+\beta_{6} \operatorname{LnAsian}_{i t}+\alpha_{i}+u_{i t}
\end{aligned}
$$

where, $\mathrm{i}=1,2, \ldots \mathrm{N}$, means $\mathrm{N}$ individuals; $\mathrm{t}=1,2, \ldots \mathrm{T}$, means $\mathrm{T}$ known time points; $\beta_{\mathrm{n}}$ is the parameter to be estimated; $u_{i t}$ is a random error term; $\alpha_{i}$ represents the individual characteristics of the cross section.

After determining the type of the random/fixed effect model, the variable intercept and variable coefficient were selected by constructing Chow to test F statistics in EVIEWS operation. The calculation formula of $F$ test is as follows:

$$
F=\frac{(R S S E-U S S E) /(N-1) k}{U S S E / N(T-k-1)} \sim F_{0.05}[(N-1) k, N(T-k-1)]
$$

where RSSE represents the sum of squared residuals of constrained regression, USSE represents the sum of squared residuals of unconstrained regression, $N$ represents the individual cross-section, $T$ represents the number of time points, and $k$ represents the number of variables. If $F>F_{0.05}$, the variable coefficient model is selected; otherwise, the variable intercept model is selected.

\section{DRIVING MERCHANISM OF CHINA'S DIRECT INVESTMENT IN THE U.S. TOURISM}

\subsection{Analysis of model results}

Due to the instability of China 's direct investment in American tourism industry, some states have sudden investment timing (for example, Kansas only received 2.6 billion US dollars in investment in 2012). In order to ensure the scientific nature of the research, this paper analyzed states with three or more years of investment between 2008 and 2017. After screening, a total of 13 states were selected as the research objects: California, Florida, Georgia, Hawaii, Illinois, Louisiana, Massachusetts, Missouri, New Jersey, New York, South Carolina, Texas and Washington.

Table I. DESCRIPTIVE STATISTICS OF VARIABLES

\begin{tabular}{|c|c|c|c|c|}
\hline Var. & $\begin{array}{c}\text { Averag } \\
\mathrm{e}\end{array}$ & S.E. & Max & Min \\
\hline TFDI & 401 & 1570 & 11711 & 0 \\
\hline GDP & $\begin{array}{c}283921 \\
2\end{array}$ & $\begin{array}{c}245972 \\
0\end{array}$ & $\begin{array}{c}1119040 \\
3\end{array}$ & 262768 \\
\hline PGDP & 53575 & 9052 & 70831 & 36352 \\
\hline
\end{tabular}

\begin{tabular}{|c|c|c|c|c|}
\hline Trade & 8.18 & 4.18 & 17.10 & 1.90 \\
\hline TGDP & 7.55 & 2.17 & 15.54 & 4.88 \\
\hline FDI & 67062 & 200394 & 1637658 & 1 \\
\hline Asian & 896799 & $\begin{array}{c}129804 \\
2\end{array}$ & 5602074 & 49260 \\
\hline
\end{tabular}

After analysis by the software Eviews, all data passed the unit root test, and reached a steady state after the first-order difference at the significance level of 5\%. The KAO cointegration test was performed on all data, with the ADF value of -2.114 and the concomitant probability of 0.017 . There was a cointegration relationship between the panel data, and individual effect model analysis could be performed.

The Hausman test identified the model as a random effects model. The result of $F$ test was $\mathrm{F}=0.853<\mathrm{F}_{0.05}(72,39)=1.626$, so the model was regarded as a variable intercept model, and the analysis results are shown in the table:

TABLE II. RESULT OF MODEL ANALYSIS

\begin{tabular}{|c|c|c|c|c|}
\hline Var. & Coff. & S.E. & T-test & Pro. \\
\hline C & $\begin{array}{c}-259.81 \\
9\end{array}$ & 52.720 & -4.928 & 0.000 \\
\hline GDP & 2.564 & 1.244 & 2.060 & 0.000 \\
\hline PGDP & 17.100 & 3.701 & 4.620 & 0.040 \\
\hline Trade & 4.634 & 1.206 & 3.844 & 0.000 \\
\hline TGDP & 16.828 & 4.371 & 3.850 & 0.000 \\
\hline FDI & 1.179 & 0.110 & $\begin{array}{c}10.75 \\
7\end{array}$ & 0.000 \\
\hline Asian & 1.415 & 0.717 & 1.972 & 0.050 \\
\hline
\end{tabular}

It can be seen from the calculation results that the coefficients of each variable had passed the significance test at the confidence level of $5 \%$, and each variable could have a positive impact on tourism direct investment, with the order of impact: GDP per capita, tourism industry output value, dependence degree of trade, GDP, Asian population and FDI. Among them, the GDP per capita and the output value of the tourism industry had a much higher driving effect on the direct investment of tourism than other variables. The dependence degree of trade had a moderate impact, while GDP, Asian population and FDI had a relatively small driving capacity for tourism direct investment.

\subsection{Analysis of driving mechanism}

Based on the above calculation results, a four-fold driving mechanism for China's direct investment in the American tourism industry was proposed:

(1) Economic development drive

GDP per capita has the strongest explanation, indicating that China's direct investment in American tourism industry attaches the most importance to the consumption power of local residents. The GDP per capita of New York State and California ranks among the top three in the United States. At the same time, the two states accounted for $35.52 \%$ and $23.41 \%$ of China's total direct investment in the US tourism industry in 2008-2017 with 23.591 billion dollars and 15.547 billion dollars, and had greatly boosted the influence of market 
size on direct investment in tourism; GDP had a positive impact on tourism direct investment, indicating that China's direct investment in the US tourism industry is mainly market-oriented, which confirmed the theory of UNCTAD ${ }^{[16]}$ (the theory believes that FDI of most service industries is market-oriented); The opening degree of economy also had certain impact on tourism FDI, and a large number of studies had affirmed that the degree of economic interconnection between the two countries would affect FDI. This paper had confirmed through calculation that this conclusion is also applicable to China's direct investment in the US tourism industry. The high degree of economic connection means that the economic entities have a high degree of trade demand and are more familiar with each other's investment environment, which is more conducive for enterprises to participate in the international production division.

(2) Tourism development drive. The tourism output value has a strong explanation, indicating that China's direct investment in the US tourism industry tends to flow to regions with a high level of tourism development. According to Deng Ning's eclectic theory of international production, enterprises tend to carry out international production in regions with great location advantages, and the location advantages include the level of industrial development. Investment in the areas with high-level industrial development can not only achieve more profitability, but also help to learn advanced foreign technology and management experience.

(3) Cultural distance drive. The number of Asians has a certain influence, because investing in the areas with similar culture can effectively eliminate the business risks caused by cultural distance. In addition, according to the competitive advantage theory of American economists Wells and Michael Porter, overseas investment in developing countries has the characteristics of "ethnic bond" [17]. Out of psychological dependence, investors prefer to invest in the regions with high cultural similarity.

(4) Institutional distance drive. In the process of direct investment in the United States, Chinese tourism enterprises must consider the restrictions of state and even county-level local government laws and regulations, the level of municipal facilities, tax differences and administrative efficiency of government. However, as a part of a unified country, each state still needs to be subject to the laws of the US federal government. Although there are institutional differences between states, but the differences are far less than that between countries, so although the institutional distance will drive the development of tourism FDI, the impact is limited.

Combining with the previous analysis of the driving force of China's tourism FDI on a macro scale, this paper believed that the special feature of driving mechanism of China's FDI in the US tourism industry was to consider the existence of the "cultural distance" between China and the states, which was related to the actual national conditions of the United States as a "multi-ethnic melting pot", which was also not covered in the previous theoretical research on tourism FDI. Although the existence of different institutional environments among states in the US is also a special national situation, the role of the institutional environment in the development of tourism FDI had been proven, so it was not recognized as innovation of this study.

\section{CONCLUSIONS AND DISCUSSION}

\subsection{Conclusions}

This paper analyzed and explored the temporal and spatial distribution characteristics and driving mechanism of China 's direct investment in the US tourism industry, and obtained the following conclusions: Factors influencing China's direct investment in the US tourism industry are ranked as: GDP per capita $>$ tourism output value $>$ dependence degree of trade $>$ GDP $>$ Asian population $>$ FDI, which was further summarized as the fourfold mechanism of China's direct investment in the US tourism industry: economic development drive, tourism development drive, cultural distance drive and institutional distance drive. The fourfold mechanisms jointly formed the basis for the location selection of China's direct investment in the tourism industry of the United States. Thereinto, the differences in cultural distances between American states are what make the United States to absorb China's tourism FDI different from that from the global macro perspective.

\subsection{Discussion}

Based on the conclusions of this study, the following two practical suggestions are proposed: First, when making direct investment decisions in the U.S. tourism industry, Chinese companies should focus on the economic development and the development of tourism economy of the investment area, and on this basis, pay attention to the synergistic effect of cultural distance and institutional distance; Second, they should attach importance to the role of "cultural affinity" in the tourism industry's outward investment activities. Chinese are the largest Asian group in the United States, so paying attention to and maintaining close contact with overseas Chinese can not only establish an international image, but also benefit overseas investment activities.

\section{Acknowledgement}

This study is funded by National Natural Science Foundation of China "The Spatial Evolution Mechanism and Location Selection of China's Direct Investment in the United States"(No.41671118).

\section{REFERENCES}

1. YANG $\mathrm{H} \mathrm{H}$, "Choice of market access mode of multinational hotels: weighing between risk and benefit," Tourism Tribune, vol.22, pp. 79-83, February 2007.

2. MA B and KOU M, "An initial study on the development of China's outbound travel and its impact," Tourism Tribune, pp.24-28, July 2006. 
3. JI Q, "How to 'go out' better for tourism enterprises under the new normal," China Tourism News, 2005-11-25(004).

4. DU J, " Internationalization of Chinese tourism enterprises -- theory, mode and realistic choice," Beijing: Tourism Education Press, 2006.

5. LI X J. "A new discussion on the transnational management of Chinese tourism industry," Beijing: China Economic Publishing House, 2010.

6. BAO F H and ZHU M N, "An analysis of the characteristics and related factors of China's foreign direct investment in tourism industry," Commercial Research, vol.483, pp. 173-177, July 2017.

7. LI X J, SONG C Y and MA L, "Analysis on the distribution characteristics and influencing factors of Chinese outbound tourism investment enterprises based on the provincial perspective," Journal of Commercial Economics, vol. 683, pp. 120-123, December 2015.

8. LI X J, Huang S S and Song C Y, "China's outward foreign direct investment in tourism," Tourism Management, vol.59, pp.1-6, April 2017.

9. TANG R, FENG X G and FENG F, "The analysis of tourism investment environment and coordination in BRICS countries," Economic Geography, vol.38, pp. 226-233, October 2018.

10. ZOU T Q, CHEN X and LIU L S, "Belt and Road' tourism investment: from resource market to tourism hub," Tourism and Hospitality Prospects, vol.5, pp.74-80, February 2018.

11. Asiedu E, "Foreign Direct investment in Africa: the role of natural resources, market size, government policy, institutions and political instability," World Economy, vol.29, pp. 63-77, January 2006.

12. HUANG Y P, HE F and ZHANG Y S, "The study of China outward foreign direct investment," Beijing: Peking University Press, 2013.

13. ZHANG C and ZHAO Q W, "Analysis on factors affecting location choice of FDI in China' s service industry," Journal of Finance and Economics, vol.34, pp. 40-54, December 2008.

14. ZHAO Q and YANG Z H, "Analysis of influence factors on FDI utilization in China' $\mathrm{s}$ advanced service industry ----based on data from year 1997 to year 2007," On Economic Problems, pp. 47-51, May 2010.

15. ZHOU M, "Intensification of geo-cultural homophily in global trade: Evidence from the gravity model," Social Science Research, vol.40, pp. 193-209, January 2011.

16. UNCTAD, "World investment report 2003. FDI policies for development: national and international perspectives," New York: United Nations, 2004.

17. HU M, "Thoughts and analysis of the transnational management of China 's tourist hotels," Journal of Guilin Institute of Tourism, vol.11, pp. 27-29, January 2000. 